\title{
Kvaliteta života laringektomiranih osoba
}

IIIIIIIIIIIIIIIIIIIIIIIIIIIIIIIIIIIIIIIIIIIIIIIIIIIIIIIIIIIIIIIIIIIIIIIIIIIIIIIIIIIIIIIIIIIIIIIIII

1 Ivana Crnković

1 Melita Rukavina

1 Karlo Ostrogonac

1 Zdravstveno veleučilište Zagreb

\section{Sažetak}

Kvaliteta života važan je evaluacijski instrument rehabilitacijskog procesa onkoloških bolesnika, pa tako i osoba s laringektomijom. Cilj ovoga istraživanja bio je ispitati stupanj kvalitete života kod osoba nakon zahvata laringektomije u cjelini i po domenama, provjeriti postoje li razlike u kvaliteti života osoba prije i nakon zahvata laringektomije u cjelini i po domenama te ispitati faktore koji utječu na samoprocjenu kvalitete života osoba nakon laringektomije. U istraživanju je sudjelovalo 35 ispitanika nakon totalne laringektomije. Upotrijebljen je prigodni uzorak s područja grada Zagreba, u Klinici za tumore KBC-a Sestre Milosrdnice u Zagrebu i Klinici za tumore KBC-a Zagreb. Za svrhe ovog istraživanja primijenjen je Indeks osobne dobrobiti za procjenu kvalitete života osoba i dobrobiti prije i poslije provedenog zahvata laringektomije te Upitnik za samoprocjenu kvalitete života EORTC QLQ-C30, verzija 3.0.

Rezultati ovog istraživanja upućuju na to da percipirana kvaliteta života osoba s laringektomijom ne odstupa od vrijednosti koje se mogu naći u zdravoj populaciji. Utvrđeno je i da ispitanici procjenjuju svoju kvalitetu života prije provođenja zahvata znatno višom. Pacijenti koji su bili uključeni u rehabilitacijski proces i koji se bave sportskom aktivnošću procjenjuju svoju kvalitetu života u prosjeku boljom i prije i nakon zahvata. Od simptoma koji su značajno povezani s osjećajem dobrobiti odnosno kvalitetom života istaknuli su se umor i gastrointestinalne smetnje, dok se skala globalnog zdravlja pokazala povezanom samo s kvalitetom života nakon zahvata.

Ključne riječi: kvaliteta života, osobe s laringektomijom, rehabilitacijski proces, samoprocjena faktora koji utječu na kvalitetu života nakon laringektomije

Datum primitka: 31.05.2015.

Datum prihvaćanja: 05.10.2015.

Adresa za dopisivanje:

Ivana Crnković, dipl. physioth.

Zdravstveno veleučilište Zagreb

Mlinarska cesta 38, 10000 Zagreb

Tel.: 091/4595-737

E-pošta: ivana.crnkovic@zvu.hr

\section{Uvod}

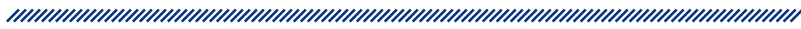

Pojam kvalitete života kod svakog pojedinca odnosi se na doživljaj zadovoljstva načinom života, njegovim tijekom i uvjetima, perspektivom, mogućnostima i ograničenjima, a predmet je istraživanja različitih znanstvenih 
disciplina ${ }^{1,2}$. Procjena kvalitete života pod utjecajem je individualnog iskustva, želja i vrijednosti pojedinca, određena je psihofiziološkim sklopom karakteristika pojedinca te objektivnim uvjetima u kojima živi. Kognitivne i konativne osobine svakog pojedinca određuju raspon i kvalitetu interakcija s okolinom, njegovu prilagodljivost promjenama u fizičkoj i socijalnoj okolini, kao i promjenama koje se zbivaju unutar organizma ${ }^{3}$.

Povezivanje pojma zdravlja i funkcioniranja s kvalitetom života neizostavna je smjernica u procesu rehabilitacije osoba s invaliditetom ${ }^{4}$. Kvaliteta života osoba s invaliditetom nije samo rezultat rehabilitacijskog procesa nego i interakcije okolnih uvjeta i psiholoških osobina pojedinca, što određuje subjektivnu procjenu kvalitete života. Svjetska zdravstvena organizacija definirala je kvalitetu života kao individualnu percepciju vlastite životne stvarnosti u svjetlu kulturalnih i vrijednosnih sustava u kojima netko živi, a s obzirom na očekivanja, vlastite ciljeve i standarde ${ }^{5}$. Istraživanja u pravilu potvrđuju postojanje povezanosti subjektivne kvalitete života, vanjskih događaja i ličnosti. Pri tome, naravno, treba uzeti u obzir prirodu vanjskog događaja, jer je za pretpostaviti da će različiti vanjski utjecaji imati i različit učinak. Loše je zdravlje nedvojbeno jedan od vanjskih čimbenika koji negativno utječe na život pojedinca ${ }^{1}$.

Utjecaj je oštećenog zdravlja na kvalitetu života višedimenzionalan. Ne samo da utječe u smislu fizičkih simptoma i time limitira funkcioniranje, nego su tu prisutni i posredni učinci kao što su to promjene u radnoj sposobnosti, potencijalna izolacija, povećanje ovisnosti o drugima, loše navike i sl. Sve to najčešće dovodi i do promjena u psihičkom stanju pojedinca. Tako se može javiti depresija, anksioznost, osjećaj bespomoćnosti, smanjeno samopouzdanje i osjećaj nedostatka kontrole. Mnoga su istraživanja pokazala da se psihička stanja, posebice anksioznost i depresivnost, javljaju kao medijatori zdravstvenog ishoda i subjektivne kvalitete života u situacijama bolesti ${ }^{1}$.

Kvaliteta života kroničnih bolesnika, posebno onkoloških bolesnika, trebala bi biti krajnji i zajednički rehabilitacijski ishod cijeloga zdravstvenog tima uključenog u liječenje. Povezivanje pojma zdravlja s kvalitetom života vrijedna je novost u medicini. Tako je i kao dostatan pokazatelj zdravlja odbačen broj godina koje čovjek proživi, jer ne pokazuje i kvalitetu čovjekova života. Pojam se kvalitete života u medicini može odrediti i kao mogućnost da nakon poduzetog liječenja bolesnik živi tjelesno, duševno i socijalno što sličnije životu prije liječenja ${ }^{6}$.
Zloćudni tumor larinksa značajan je javnozdravstveni problem u svijetu jer čini oko $2 \%$ svih zloćudnih tumora u organizmu i $25 \%$ svih zloćudnih tumora glave i vrata, što ga stavlja na drugo mjesto po učestalosti među zloćudnim tumorima glave i vrata ${ }^{7}$. Većina su zloćudnih tumora larinksa (oko $99 \%$ ) planocelularni karcinomi, dok su ostali, poput adenokarcinoma, hondrosarkoma, cilindroma i slično, izrazito rijetki ${ }^{8}$. Prema podatcima Registra za tumore Hrvatskog zavoda za javno zdravstvo (HZJZ) u 2012. incidencija karcinoma larinksa u Hrvatskoj bila je 14,1 novooboljelih na 100000 stanovnika. Karcinom larinksa najčešći je u šestom i sedmom desetljeću života te češće obolijevaju muškarci ${ }^{9}$. Samo $1 \%$ slučajeva karcinoma larinksa pojavljuje se u osoba mlađih od 30 godina, a u literaturi su opisani i sporadični slučajevi u djece bez rizičnih čimbenika ${ }^{10}$. Tri modaliteta liječenja karcinoma larinksa čine kirurški zahvat, radioterapija i kemoterapija. Specifičnost je liječenja onkološke populacije da postupak koji je bio primijenjen u svrhu liječenja i izlječenja rezultira narušavanjem kvalitete života. U svrhu evaluacije rehabilitacijskog ishoda potrebno je uzeti u obzir postoperativne, funkcijske i estetske rezultate primarnog liječenja karcinoma larinksa kao važne parametre kod zaključivanja o kvaliteti života pojedinaca nakon laringektomije. Rezultati različitih studija su pokazali da je zahvat utjecao na kvalitetu života pacijenata tijekom prvih nekoliko mjeseci nakon totalne laringektomije ${ }^{11,12}$.

Sigurno je da su stadij bolesti i opseg resekcije od krajnje važnosti kod određivanja ishoda liječenja, no potrebno je utvrditi i objektivizirati faktore koji narušavaju kvalitetu života pojedinca nakon laringektomije, kao što su bol, poteškoće s gutanjem, hranjenjem i govorom, jer i minimalno poboljšanje kvalitete života pozitivno utječe na postoperativni ishod rehabilitacije.

Uzimajući u obzir ranije navedeno, ciljevi ovog istraživanja bili su:

1. ispitati stupanj kvalitete života kod osoba nakon zahvata laringektomije u cjelini i po domenama

2. provjeriti postoje li razlike u procjeni kvalitete života osoba prije i nakon zahvata laringektomije u cjelini i po domenama

3. ispitati povezanost različitih faktora sa samoprocjenom kvalitete života osoba nakon laringektomije. 


\section{Metode}

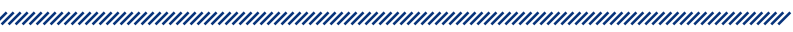

\section{Uzorak}

U istraživanju je sudjelovalo 35 ispitanika nakon totalne laringektomije. Svim ispitanicima uključenima u istraživanje dijagnosticiran je tumor larinksa, prema klasifikaciji T3 i T4. Upotrijebljen je prigodni uzorak s područja grada Zagreba, u Klinici za tumore KBC-a Sestre Milosrdnice u Zagrebu i Klinici za tumore KBC-a Zagreb, koji su aktivni članovi Hrvatske zajednice laringektomiranih osoba. $U$ istraživanju je sudjelovalo ukupno 33 muškarca $(94,3 \%)$ i dvije žene (5,7 \%). Većina ispitanika ima srednju stručnu spremu (njih 65,7 \%), zatim slijede viša $(11,4 \%)$ i visoka stručna sprema $(11,4 \%)$ te osnovna škola $(8,6 \%)$ i bez završene škole (2,9 \%). Većina je ispitanika u braku (51,4\%), podjednak broj je rastavljenih $(17,1 \%)$ i udovaca (14,3\%), a najmanje ima ispitanika koji su sami (11,4\%) i u vezi (5,7\%). Uzorak je vrlo heterogen što se tiče vremena proteklog od postavljanja dijagnoze i prosjek iznosi 5,4 godine $(S D=5,16)$, s tim da najkraće vrijeme od postavljanja dijagnoze do ispunjavanja upitnika iznosi dva mjeseca, a najduže 20 godina. Vrijeme proteklo od samog zahvata pa do ispunjavanja upitnika u prosjeku iznosi 4,9 godina $(S D=4,57)$, s rasponom od mjesec dana do 16 godina.

\section{Mjerni instrumenti}

Za procjenu kvalitete života osoba prije i poslije provedenog zahvata laringektomije primijenjen je Indeks osobne dobrobiti (engl. Personal Wellbeing Index, PWI, Cummins i sur., 2003 ${ }^{13}$ ). PWI je sastavni dio Međunarodnog Indeksa dobrobiti (International Well Being Index - IWI) koji obuhvaća Indeks osobne dobrobiti i Indeks nacionalne dobrobiti (engl. National Wellbeing Index, NWI). U ovom istraživanju primijenjen je Indeks osobne dobrobiti koji se sastoji od sedam čestica koje se procjenjuju na Likertovoj skali od 0 do 10 ( $0=$ nimalo nisam zadovoljan, $5=$ ni zadovoljan ni nezadovoljan, $10=u$ potpunosti sam zadovoljan). Svaki se rezultat dobiven na Likertovoj skali pretvara u standardni oblik prema formuli (rezultat/X) x 100, pri čemu X označava maksimalnu vrijednost na Likertovoj skali koja iznosi 10. Na taj se način dobivaju rezultati s rasponom od 0 do 100 , pri čemu veći rezultat ukazuje na veći stupanj zadovoljstva životom. Rezultati se mogu analizirati zasebno po domenama ili se zbroje procjene na svim česticama te se računa prosječan rezultat za cijelu skalu ${ }^{14}$. Na taj se način omogućava usporedba s rezultatima dobivenima u istraživanjima u Hrvatskoj i drugim zemljama. U prethodnim istraživanjima utvrđene su dobre metrijske karakteristike ovog indeksa na hrvatskoj populaciji ${ }^{15}$.

Za samoprocjenu kvalitete života primijenjen je upitnik EORTC QLQ-C30, verzija 3.0. (European Organization for Research and Treatment of Cancer's Quality of Life Questionnaire; Aaronson i sur., 1993 ${ }^{16}$ ). Upitnik se sastoji od pet funkcionalnih skala: tjelesno funkcioniranje (pet čestica), poslovno funkcioniranje (dvije čestice), kognitivno funkcioniranje (dvije čestice), emocionalno funkcioniranje (četiri čestice) i socijalno funkcioniranje (dvije čestice); te tri skale simptoma: umor (tri čestice), bol (dvije čestice), mučnina/povraćanje (dvije čestice); skale općeg zdravstvenog statusa / kvalitete života (dvije čestice) i šest individualnih čestica simptoma najčešće povezanih $s$ malignim oboljenjem: teškoće disanja, gubitak apetita, poremećaji spavanja, konstipacija, dijarea i financijske teškoće kao posljedica bolesti i tretmana. Ukupno se sastoji od 30 čestica. Sve čestice bodovane su na Likertovoj skali od 1 do 4, pri čemu 1 znači nimalo, a 4 izrazito. Iznimka je skala općeg zdravlja / kvalitete života bodovana na linearnoj analognoj skali od sedam bodova. Procjena kvalitete života odnosi se na razdoblje od sedam dana koji su prethodili ispitivanju. Svi su rezultati dobiveni na funkcionalnim skalama, kao i pojedinim česticama, linearno transformirani i pretvoreni u skalu od 0 do 100 , pri čemu viši rezultat na funkcionalnim skalama označava bolje funkcioniranje, dok visok rezultat na skalama simptoma označava prisutnost većeg broja simptoma odnosno problema. Rezultati su transformirani prema formuli: Rezultat $=(1-(S R-1) /$ raspon $) \times 100$ kod funkcionalnih skala te Rezultat $=(S R-1 /$ raspon $) \times 100$ kod skala simptoma, individualnih čestica simptoma te skale općeg zdravlja. Sirovi je rezultat prosječan rezultat na svakoj skali, a raspon se odnosi na razliku između najveće (4) i najmanje (1) moguće procjene na Likertovoj skali te većina čestica, osim skale globalnog zdravlja, gdje raspon iznosi 6 , ima raspon $3^{17}$. Na taj način omogućena je usporedba s vrijednostima koje su dobivene u drugim istraživanjima na uzorcima onkoloških bolesnika. Primijenjen je hrvatski prijevod upitnika koji je pokazao dobre metrijske karakteristike za uzorak ispitanika s malignim oboljenjem i bez njega ${ }^{18}$.

\section{Postupak}

Istraživanje se provodilo od početka siječnja do kraja travnja 2015. godine. Anketiranje sudionika provedeno 
je u prostorima Klinike za tumore, KBC-a Zagreb i KBC-a Sestre Milosrdnice, nakon timskih sastanaka Hrvatske zajednice laringektomiranih osoba. Provedbu istraživanja odobrili su predstojnik Klinike za kirurgiju glave i vrata $\mathrm{KBC}$-a Zagreb te predsjedništvo Hrvatske zajednice laringektomiranih osoba. Svi ispitanici informirani su u koju se svrhu istraživanje provodi te su svi sudionici dobrovoljno pristali sudjelovati u istraživanju. Upute za ispunjavanje nalazile su se na početku upitnika. Svi su ispitanici samostalno rješavali upitnik. Prvi se dio upitnika odnosio na sociodemografske podatke ispitanika te podatke o samoj bolesti (npr. vrijeme proteklo od postavljanja dijagnoze, operativnog zahvata te uključenosti u rehabilitacijski proces), zatim se tražilo da retrogradno procjene kvalitetu života / osjećaj dobrobiti prije provedenog zahvata laringektomije te na kraju procjene kvalitetu života nakon provedenog zahvata. Vrijeme potrebno za ispunjavanje cjelokupnog upitnika bilo je 20 minuta. Nacrt i postupak istraživanja osmišljen je i ostvaren u skladu s općim načelima provedbe istraživanja u kojima su sudionici ljudi.

\section{Rezultati}

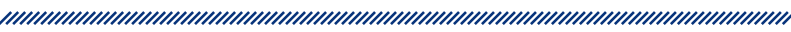

\section{Sociodemografske karakteristike ispitanika}

Prosječna dob ispitanika iznosila je 63,23 godine $(\mathrm{SD}=8,9)$, pri čemu je najmlađi ispitanik imao 41 godinu, a najstariji 82 . Većina ispitanika bila je nakon zahvata uključena u rehabilitacijski proces (25 ili 71,4 \%), dok deset ispitanika nije bilo u procesu rehabilitacije (28,6\%). Od njih 35 trenutačno je 20 ispitanika (57,1\%) uključeno u neki proces rehabilitacije, dok 15 nije $(42,9 \%)$. Sportskom se aktivnošću bavi 16 ispitanika $(45,7 \%)$, a $19(54,3 \%)$ se ne bavi nikakvom sportskom aktivnošću. Od onih koji su angažirani u neku sportsku aktivnost, svi se s tim sportom bave rekreativno.

\section{Razlike u procjeni kvalitete života osoba prije i nakon zahvata laringektomije}

Kako bi se odgovorilo na prvi cilj istraživanja koji je bio ispitati kako pacijenti s provedenom laringektomijom procjenjuju svoju dobrobit odnosno kvalitetu života prije i nakon zahvata, prikazali smo osnovne deskriptivne parametre (tablica 1).

Dobiveni rezultati ukazuju na to da osobe s laringektomijom po procjeni kvalitete života ne odstupaju od vrijednosti koje se mogu naći u zdravoj populaciji. Procjena osobne dobrobiti odnosno kvalitete života, i prije i nakon zahvata, kreće se u okvirima od 60 do $80 \%$ skalnog maksimuma, što se prema homeostatskom modelu smatra rezultatom unutar prosjeka koji postižu zdrave osobe ${ }^{19}$.

Kako bismo provjerili postoje li statistički značajne razlike u procjeni zadovoljstva životom pacijenata prije i poslije zahvata laringektomije, proveli smo t-test za zavisne uzorke koji je pokazao da postoji statistički značajna razlika ( $t=3,122 ; p=0,004)$. Iz tablice 1 može se vidjeti da ispitanici procjenjuju značajno višom svoju kvalitetu života prije provođenja zahvata.

Promatrajući zadovoljstvo životom po pojedinim domenama Indeksa osobne dobrobiti možemo vidjeti da su pacijenti najviše zadovoljni domenom odnosa s bližnjima, osjećajem sigurnosti te pripadnosti okolini u kojoj žive kako prije tako i nakon provođenja zahvata laringektomije (vidi tablicu 2).

Kako bismo dobili bolji uvid u faktore koji mogu biti povezani s procjenom zadovoljstva životom prije i nakon zahvata, usporedili smo te varijable s varijablama uključenost u rehabilitacijski proces, prije i sada te uključenost u sportske aktivnosti (tablica 3).

Rezultati t-testa pokazali su da postoje statistički značajne razlike u procjeni kvalitete života kod pacijenata prije i nakon laringektomije ovisno o tome jesu li prije bili uključeni u rehabilitacijski proces i bave li sportskom aktivnošću.

Na temelju prosječnih vrijednosti možemo zaključiti da pacijenti koji su bili uključeni u rehabilitacijski proces i koji se bave sportskom aktivnošću procjenjuju svoju

Tablica 1. Prikaz prosječnih vrijednosti za zadovoljstvo prije zahvata i zadovoljstvo poslije zahvata na Indeksu osobne dobrobiti (PWI)

\begin{tabular}{|c|c|c|c|c|c|c|}
\hline VARIJABLA & N & MIN. & MAKS. & M & SD \\
\hline PWI PRIJE ZAHVATA & 35 & 0 & 95,00 & 74,8 & 19,86 \\
\hline PWI POSLIJE ZAHVATA & 35 & 28,75 & 97,5 & 67,6 & 17,96 \\
\hline
\end{tabular}


kvalitetu života u prosjeku boljom i prije i nakon zahvata, dok nema razlika u procjeni kvalitete života kod onih koji su trenutačno u rehabilitaciji u odnosu na one koji nisu uključeni u taj proces.

\section{Povezanost različitih faktora sa samoprocjenom kvalitete života osoba nakon laringektomije}

Kako bi se dobio uvid u specifične poteškoće s kojima se pacijenti oboljeli od raka grla suočavaju te njihovoj kvaliteti života, izračunane su prosječne vrijednosti na temelju rezultata upitnika EORTC QLQ-C30 (vidi tablicu 4).
Može se vidjeti da ispitanici postižu relativno visoke rezultate na svim funkcionalnim skalama, što ukazuje na prosječno dobro funkcioniranje u tim područjima. Također, niži rezultati na svim skalama simptoma ukazuju na to da ispitanici nakon laringektomije ne izvještavaju o prisutnosti mnogo simptoma koji bi im mogli remetiti njihovo funkcioniranje.

Zanimalo nas je i kakva je povezanost procjene kvalitete života na pojedinim funkcionalnim skalama i simptomima iz upitnika EORTC QLQ-C30 s indeksom osobne dobrobiti prije i poslije zahvata laringektomije. Prikazane su samo statistički značajne korelacije (vidi tablicu 5). Rezultati pokazuju da je kvaliteta života ispitanika prije

\begin{tabular}{|c|c|c|c|}
\hline VARIJABLA & $\mathrm{N}$ & M & SD \\
\hline \multicolumn{4}{|c|}{ PWI PRIJE ZAHVATA } \\
\hline Životni standard & 35 & 70,57 & 20,996 \\
\hline Zdravlje & 35 & 75,71 & 21,459 \\
\hline Postignuće & 35 & 72,00 & 21,936 \\
\hline Odnosi s bližnjima & 35 & 77,43 & 24,174 \\
\hline Osjećaj sigurnosti & 35 & 76,57 & 22,744 \\
\hline Pripadnost okolini & 35 & 76,00 & 24,994 \\
\hline Sigurnost u budućnost & 35 & 72,86 & 25,961 \\
\hline \multicolumn{4}{|c|}{ PWI NAKON ZAHVATA } \\
\hline Životni standard & 35 & 64,86 & 21,471 \\
\hline Zdravlje & 35 & 61,43 & 25,222 \\
\hline Postignuće & 35 & 63,71 & 26,244 \\
\hline Odnosi s bližnjima & 35 & 73,43 & 24,003 \\
\hline Osjećaj sigurnosti & 35 & 67,43 & 23,053 \\
\hline Pripadnost okolini & 35 & 72,29 & 24,385 \\
\hline Sigurnost u budućnost & 35 & 65,71 & 27,470 \\
\hline
\end{tabular}

Tablica 3. Prikaz prosječnih vrijednosti za varijablu zadovoljstvo životom prije i poslije zahvata s obzirom na varijable uključenost $u$ rehabilitacijski proces - prije i sada te bavljenje sportskom aktivnošću i prikaz rezultata t-testa

\begin{tabular}{|c|c|c|c|c|c|c|c|c|c|c|c|}
\hline \multirow{2}{*}{\multicolumn{2}{|c|}{ VARIJABLE }} & \multicolumn{5}{|c|}{ PWI PRIJE } & \multicolumn{5}{|c|}{ PWI POSLIJE } \\
\hline & & $\mathrm{N}$ & $\mathrm{M}$ & SD & $t$ & $\mathrm{p}$ & $\mathrm{N}$ & $\mathrm{M}$ & SD & $t$ & $\mathrm{p}$ \\
\hline \multirow{2}{*}{$\begin{array}{l}\text { REHABILITACIJA } \\
\text { PRIJE }\end{array}$} & $\mathrm{Da}$ & 25 & 81,9 & 9,42 & \multirow{2}{*}{4,277} & \multirow{2}{*}{0,000} & 25 & 73,5 & 13,17 & \multirow{2}{*}{3,895} & \multirow{2}{*}{0,000} \\
\hline & $\mathrm{Ne}$ & 10 & 55,8 & 27,1 & & & 10 & 50,6 & 21,17 & & \\
\hline \multirow{2}{*}{$\begin{array}{l}\text { REHABILITACIJA } \\
\text { POSLIJE }\end{array}$} & $\mathrm{Da}$ & 20 & 78,1 & 12,59 & \multirow{2}{*}{1,249} & \multirow{2}{*}{0,221} & 20 & 70,6 & 16,16 & \multirow{2}{*}{1,350} & \multirow{2}{*}{0,186} \\
\hline & $\mathrm{Ne}$ & 15 & 69,6 & 26,65 & & & 15 & 62,1 & 21,34 & & \\
\hline \multirow{2}{*}{$\begin{array}{l}\text { SPORTSKA } \\
\text { AKTIVNOST }\end{array}$} & $\mathrm{Da}$ & 16 & 84,3 & 6,56 & \multirow{2}{*}{2,96} & \multirow{2}{*}{0,006} & 16 & 77,1 & 11,52 & \multirow{2}{*}{3,356} & \multirow{2}{*}{0,002} \\
\hline & $\mathrm{Ne}$ & 19 & 66,16 & 23,66 & & & 19 & 58,4 & 19,62 & & \\
\hline
\end{tabular}


zahvata statistički značajno povezana samo s emocionalnim funkcioniranjem od funkcionalnih skala upitnika EORTC QLQ-C30 na način da što je bolje njihovo emocionalno funkcioniranje, odnosno što doživljavaju manje negativnih emocija kao što su napetost, depresija, zabrinutost i razdražljivost to je procjena njihove kvalitete života bolja i prije i nakon zahvata. Od simptoma koji su značajno povezani s osjećajem dobrobiti odnosno kvalitetom života istaknuli su se umor, mučnina/ povraćanje te proljev. Više simptoma na tim skalama povezano je s nižim procjenama kvalitete života prije i poslije zahvata. Skala globalnog zdravlja pokazala se povezanom samo s kvalitetom života nakon zahvata.

\section{Diskusija}

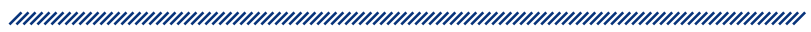

Kvaliteta života i prilagodba na kroničnu bolest već je dugi niz godina interes različitih istraživača i stručnjaka koji uspoređuju bolesnu i zdravu populaciju te istražuju faktore koji u toj prilagodbi mogu pomoći. Laringektomirani pacijenti suočavaju se s nekim specifičnim poteškoćama zbog prirode svoje bolesti i posljedica koje može ostaviti po njihovo svakodnevno funkcioniranje. Dobiveni rezultati u ovom istraživanju ukazuju na to da osobe s laringektomijom po procjeni kvalitete života ne odstupaju od vrijednosti koje se mogu naći u zdravoj populaciji. Perci-

\begin{tabular}{|c|c|c|c|}
\hline $\begin{array}{l}\text { Tablica 4. Prikaz prosječnih vrijednosti po pojedinim skalama i česticama iz } \\
\text { Upitnika kvalitete života osoba oboljelih od karcinoma }\end{array}$ \\
\hline VARIJABLA & N & M & SD \\
\hline Tjelesno funkcioniranje & 35 & 83,4 & 23,4 \\
\hline Poslovno funkcioniranje & 35 & 78,6 & 78,6 \\
\hline Kognitivno funkcioniranje & 35 & 86,7 & 24,5 \\
\hline Emocionalno funkcioniranje & 35 & 73,6 & 24,5 \\
\hline Socijalno funkcioniranje & 35 & 80,0 & 26,1 \\
\hline Umor & 35 & 25,4 & 25,8 \\
\hline Bol & 35 & 24,8 & 32,7 \\
\hline Mučnina/povraćanje & 35 & 9,5 & 19,1 \\
\hline Opći zdravstveni status & 35 & 65,7 & 30,3 \\
\hline Teškoće disanja & 35 & 20,9 & 30,3 \\
\hline Gubitak apetita & 35 & 12,4 & 29,2 \\
\hline Poremećaji spavanja & 35 & 28,6 & 35,4 \\
\hline Konstipacija & 35 & 18,1 & 30,6 \\
\hline Dijarea & 35 & 15,2 & 31,7 \\
\hline Financijske poteškoće & 35 & 32,4 & 36,6 \\
\hline
\end{tabular}

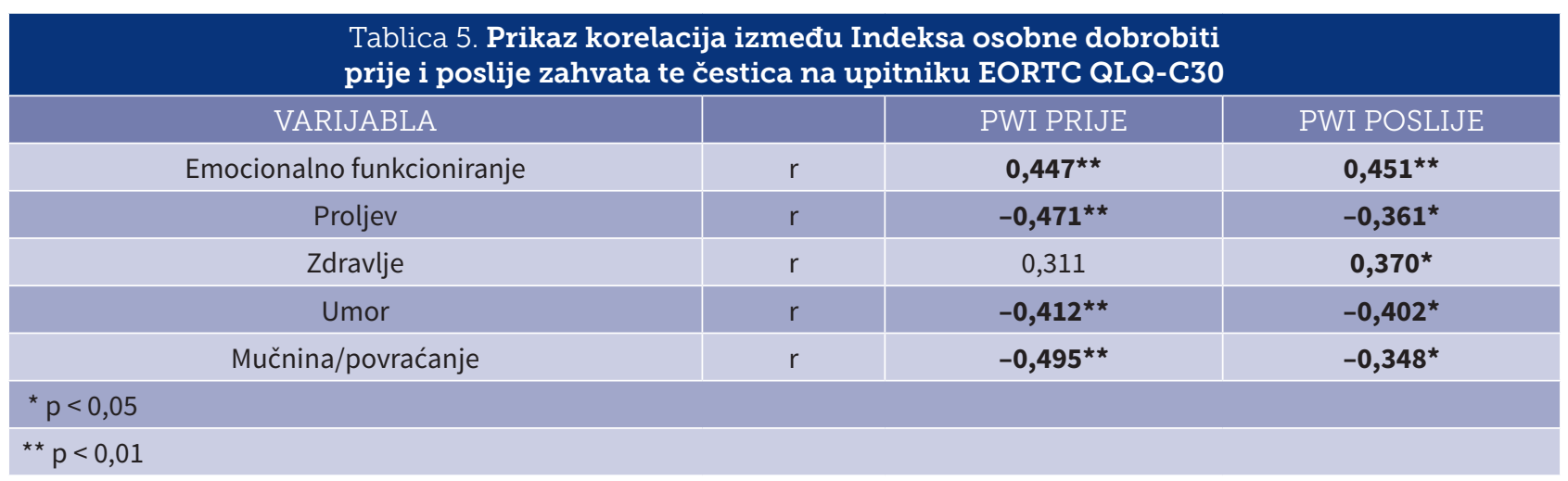


pirana kvaliteta života, i prije i nakon zahvata, kreće se u okvirima od 60 do $80 \%$ skalnog maksimuma, što se prema homeostatskom modelu smatra rezultatom unutar prosjeka koji postižu zdrave osobe ${ }^{19}$.

Totalna laringektomija podrazumijeva kirurški zahvat na glavi i vratu s različitim posljedicama koje se odnose na kvalitetu života bolesnika i opći osjećaj blagostanja. Najočiglednija invalidnost odnosi se na gubitak mogućnosti govora, no i druge funkcionalne poteškoće mogu bitno pridonijeti ukupnoj kvaliteti života bolesnika ${ }^{20,21}$. Spomenuti operativni zahvati, kao i kirurško odstranjenje drugih opsežnih tumora glave i vrata, neizbježno imaju za posljedicu gubitak vitalnih funkcija kao što su gutanje, govor i njuh. U novonastalim anatomskim uvjetima gornji dišni sustav više nema respiratornu ulogu, disanje se odvija kroz traheostomu, a fonacija je nemoguća ${ }^{22}$, što objašnjava dobivene rezultate ovog istraživanja, da ispitanici procjenjuju značajno višom svoju kvalitetu života prije provođenja zahvata.

Društvena podrška i obitelj najvažniji su izvor potpore laringektomiranom pacijentu. Rezultati mnogih studija upućuju na zaključke da je, između ostalog, u procesu liječenja kronične bolesti nužno aktivno uključivanje obitelji23. Studije su pokazale da na obitelj orijentirano liječenje kroničnih bolesti predstavlja napredak u liječenju u odnosu na tradicionalno liječenje orijentirano na bolest ili pojedinačnog bolesnika. Napredak je vidljiv i u rezultatima liječenja i ishodu bolesti ${ }^{24}$. Inkluzija je osoba s laringektomijom u društvenu zajednicu u svim nivoima pravo, a ne poteškoća, i kao takva je u društvu pouzdan indikator postignutog stupnja njegove demokratizacije. Većina je ispitanika koja je sudjelovala u ovom istraživanju u braku i svi su članovi zajednice laringektomiranih osoba. Ovaj podatak ukazuje na trend uključivanja pacijenta i njegove obitelji, kao modela liječenja onkoloških bolesnika, u zajednicu u najranijoj fazi liječenja postoperativne skrbi. Stoga rezultat dobiven u ovom istraživanju, da su pacijenti najviše zadovoljni odnosima s bližnjima, osjećajem sigurnosti te pripadnosti okolini u kojoj žive, kako prije tako i nakon provođenja zahvata laringektomije, govori u prilog činjenici da obitelj i društvena podrška imaju značajnu ulogu u ishodu liječenja i integraciji osobe s laringektomijom u život zajednice.

Laringektomirani pacijenti, od trenutka postavljanja dijagnoze pa sve do zahvata laringektomije i uključivanja u rehabilitacijski proces, prolaze kroz različite faze prilagodbe na novonastalu situaciju. Faktori su koji su se pokazali osobito važnima za kvalitetu života uključenost u proces rehabilitacije te sportska aktivnost (vidi tabli- cu 4). Rehabilitacijski proces važna je komponenta koja utječe na subjektivnu dobrobit onkoloških pacijenata. Laringektomirani pacijenti spadaju u skupinu kroničnih pacijenata gdje je subjektivna procjena kvalitete života povezana sa slabijim i sporijim oporavkom, daljnjom progresijom bolesti, pa čak i preživljavanjem. Interdisciplinarni pristup koji provodi rehabilitacijski tim obuhvaća predoperativno i postoperativno savjetovanje i pružanje podrške bolesniku i obitelji; organiziranje predoperativnog posjeta laringektomirane osobe; podršku i dopunu rehabilitaciji glasa, govora, gutanja i mirisanja; informiranje i edukaciju operiranih članova i obitelji; informiranje i pomoć u ostvarivanju prava; organiziranje grupe psihološke potpore; poticanje socijalizacije te poticanje razvoja svijesti lokalne zajednice o laringektomiranim osobama i njihovim potrebama ${ }^{25}$. Istraživanja upućuju na to da su rehabilitacijski timovi u kombinaciji $\mathrm{s}$ integriranim rehabilitacijskim programom najdjelotvorniji u poboljšanju kvalitete života oboljele osobe ${ }^{26}$. Prema modelu Svjetske zdravstvene organizacije Sport for Development and Peace International Working Group $(2007)^{27}$, utjecaj sporta i tjelesne aktivnosti očituje se na sve domene kvalitete života, naglašavajući pritom preventivni utjecaj fizičke aktivnosti kod osoba s invaliditetom i različitih dobnih skupina standardne populacije. Važno je naglasiti da tjelesna aktivnost ima preventivnu ulogu u očuvanju zdravlja, ali isto tako i rehabilitacijsku i habilitacijsku ulogu posebno kod osoba s invaliditetom. Uključivanje osoba s invaliditetom u sportske aktivnosti omogućuje inkluziju pojedinaca s invaliditetom u širu društvenu zajednicu, stjecanje novih motoričkih i socijalnih vještina te se kroz učenje specifičnih motoričkih zadataka osobe s invaliditetom maksimalno koriste preostalim motoričkim sposobnostima, čime se utječe na postizanje njihove maksimalno moguće neovisnost unutar granica njihovih funkcionalnih sposobnosti. Istraživanja niza autora ${ }^{4,28-31}$ potvrdila su pozitivnu povezanost uključenosti osoba s invaliditetom u programe vježbanja i uključenosti u sportske aktivnosti u odnosu na analizirane domene kvalitete života, što je u skladu s rezultatima koji su dobiveni u ovom istraživanju.

Rezultati na upitniku EORTC QLQ-C30 pokazuju da ispitanici postižu relativno visoke rezultate na svim funkcionalnim skalama, što ukazuje na prosječno dobro funkcioniranje u tim područjima. Također, niži rezultati na svim skalama simptoma ukazuju da ispitanici nakon laringektomije ne izvještavaju o prisutnosti mnogo simptoma koji bi mogli remetiti njihovo funkcioniranje. Ovakav rezultat govori u prilog činjenici da trenutačna pojavnost simptoma uzrokovanih primarnim liječenjem karcinoma 
larinksa nisu primarni čimbenici koji utječu na samoprocjenu kvalitete života onkološkog pacijenata. Autorica Pinjatela (2008) proučavala je karakteristike kvalitete života osoba s malignim oboljenjem i bez njega ${ }^{18}$. Rezultati istraživanja pokazali su da oboljeli od malignih bolesti doživljavaju manje teškoća prilikom tjelesnih aktivnosti, manje emocionalnih problema, manje simptoma umora i boli, ali više fizioloških simptoma (mučnina, povraćanje), više teškoća u socijalnom funkcioniranju i više financijskih teškoća u odnosu na ispitanike bez oboljenja. Ispitanici su, bez obzira na dobar funkcionalan status i manju prisutnost simptoma, značajno manje zadovoljni svojim ukupnim zdravstvenim stanjem i kvalitetom života od ispitanika bez malignog oboljenja. I u ovom je istraživanju dobiveno da bolesnici izjavljuju o postojanju manje poteškoća na funkcionalnim skalama, a da je kvaliteta života značajno povezana s prisutnošću simptoma poput umora, mučnine i proljeva.

Od funkcionalnih skala upitnika EORTC QLQ-C30 kvaliteta života ispitanika statistički je značajno povezana samo s emocionalnim funkcioniranjem. Pacijenti koji izvještavaju da su manje napeti, depresivni, zabrinuti i razdražljivi, odnosno dobro emocionalno funkcioniraju i nose se s bolešću, procjenjuju svoju kvalitetu života boljom i prije i nakon zahvata. Što se tiče simptoma i kvalitete života, značajno su povezani umor, mučnina/ povraćanje te proljev. Više simptoma na tim skalama povezano je s nižim procjenama kvalitete života prije i poslije zahvata. Skala globalnog zdravlja pokazala se povezanom samo s kvalitetom života nakon zahvata. Gastrointestinalni simptomi, poteškoće disanja i bol kod laringektomiranih osoba rezultiraju pojavnošću umora koji kao simptom navode ispitanici obuhvaćeni ovim istraživanjem. Pojavnost ovih simptoma koja je u pozitivnoj korelaciji s kvalitetom života utvrdili su i autori Mallis i sur. (2011) u istraživanju čimbenika koji utječu na ukupnu kvalitetu života nakon totalne laringektomije. Rezultat istraživanja bio je da dio pacijenata ima narušen obiteljski i seksualni život (23,9\%), dio pacijenata ima smanjenu participaciju u socijalnim događanjima (23,9\%), velik dio pacijenata navodi pogoršanje financijske situacije, sposobnost za rad te visoku stopu umirovljenja $(80,5 \%)$, dio pacijenata navodi gutanje i poremećaj prehrane kao problem (15,2\%), a bol u manjem broju slučajeva (4,2\%), velik dio pacijenata istaknuo je nelagodu zbog svoje pojave $(58,7 \%)$ te pojavu osjećaja usamljenosti $(30,4 \%)^{32}$. Identifikacija simptoma koji utječu na ukupnu kvalitetu života laringektomiranih pacijenata daje doprinos izradi kliničkih smjernica u rehabilitaciji i liječenju onkoloških pacijenata.

\section{Prednosti i nedostatci provedenog istraživanja}

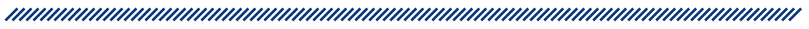

Ovo istraživanje daje smjernice za daljnja istraživanja povezana s kvalitetom života osoba s laringektomijom. Prednost je ovog istraživanja i deskriptivna analiza kvalitete života osoba s laringektomijom prije i nakon zahvata te procjena faktora koji utječu na samoprocjenu kvalitete života osoba nakon laringektomije. U prikazanom istraživanju istaknuta je važnost utjecaja bolesti i tretmana na kvalitetu života kod određivanja ishoda liječenja. Praktična je vrijednost rada i identifikacija ključnih faktora koji narušavaju kvalitetu života pojedinca nakon laringektomije, kao što su bol, poteškoće s gutanjem, hranjenjem i govorom te gastrointestinalne poteškoće i njihova povezanost s ukupnom kvalitetom života i zdravljem u cijelosti, što pridonosi razvoju intervencija u procesu liječenja.

Također, postoje neki metodološki nedostatci koji ne dopuštaju donošenje zaključaka o uzročno-posljedičnoj povezanosti kvalitete života i faktora koji utječu na samoprocjenu kvalitete života osoba nakon laringektomije. Veličina uzorka ne dozvoljava generalizaciju ovih rezultata, stoga je potrebno obuhvatiti ispitanike sa šireg područja Republike Hrvatske te uzeti u probir $\mathrm{i}$ stanovnike neurbanih sredina. Potrebno bi bilo i usporediti kvalitetu života osoba s laringektomijom ovisno o spolu te homogenizirati uzorak po pitanju vremena proteklog od postavljanja dijagnoze i uključenosti u rehabilitacijskih proces. Također, procjenu kvalitete života prije zahvata laringektomije ispitanici su procjenjivali retrogradno, što je moglo utjecati na rezultate. Praćenje ispitanika i njihove kvalitete života kroz duži period, od postavljanja dijagnoze do procesa rehabilitacije nakon provedene laringektomije, omogućilo bi praćenje promjena kroz koje bolesnici prolaze. Metodološki je nedostatak istraživanja i neprilagođenost upitnika za identifikaciju faktora koji utječu na samoprocjenu kvalitete života laringektomiranih osoba. U daljnjim bi istraživanjima bilo potrebno provesti evaluaciju faktora koji utječu na samoprocjenu kvalitete života, prilagođenog za osobe sa laringektomijom, npr. putem upitnika University of Washington Quality of Life Questionnaire (UWQOL). Zbog manjka stručne literature povezane $s$ područjem kvalitete života laringektomiranih pacijenata, bilo bi potrebno provesti longitudinalne studije koje bi kroz dulji vremenski period istraživale odnos kvalitete života osoba s laringektomijom te faktora koji utječu na njihovu samoprocjenu, u postoperativnoj skrbi. 


\section{Zaključak}

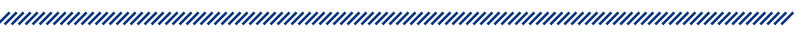

Kvaliteta života temeljena na zdravlju u onkologiji mora biti krajnji ishod i evaluacija rehabilitacijskog procesa za svakog onkološkog bolesnika, pa tako i za osobe sa laringektomijom. U skladu s postavljenim ciljevima, ovim istraživanjem utvrđeno je da percipirana kvaliteta života osoba s laringektomijom, čija se procjena provodila putem Indeksa osobne dobrobiti (PWI), ne odstupa od vrijednosti koje se mogu naći u zdravoj populaciji. Osobe s laringektomijom procjenjuju značajno višom svoju kvalitetu života prije provođenja zahvata te su najviše zadovoljne odnosima s bližnjima, osjećajem sigurnosti te pripadnosti okolini u kojoj žive kako prije tako i nakon provođenja zahvata laringektomije. Pacijenti koji su bili uključeni u rehabilitacijski proces i koji se bave sportskom aktivnošću procjenjuju svoju kvalitetu života u prosjeku boljom i prije i nakon zahvata. Ovi rezultati govore u prilog činjenici kako bavljenje tjelesnom aktivnošću te inkluzija onkoloških pacijenata i njihovih obitelji u društvenu zajednicu pridonose uspješnijem rehabilitacijskom ishodu čiji je krajnji cilj kvaliteta života. U svrhu objektivizacije faktora koji narušavaju kvalitetu života pojedinca nakon laringektomije primijenjen je upitnik za samoprocjenu kvalitete života EORTC QLQC30, čiji su rezultati pokazali kako je pojavnost simptoma umora i gastrointestinalnih smetnji značajno povezana sa samoprocjenom kvalitete života. Rezultati ovog istraživanja ukazuju na to kako bi se kliničke smjernice za rehabilitaciju i liječenje morale usmjeriti upravo na pojavnost simptoma koji utječu na kvalitetu života onkoloških pacijenata.

\section{Literatura}

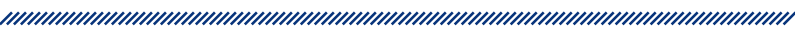

1. Vuletić G. Samoprocijenjeno zdravlje i kvaliteta života u Bjelovarsko-bilogorskoj županiji. Radovi Zavoda za znanstvenoistraživački i umjetnički rad u Bjelovaru. 2013; sv. 7:213-222.

2. Krizmanić M, Kolesarić V. Pokušaj konceptualizacije pojma „kvaliteta života”. Primijenjena psihologija. 1989; 10:179-184.

3. Petz B i sur. Psihologijski rječnik. Jastrebarsko: Naklada Slap; 2005.

4. Crnković I, Rukavina M. Sport i unapređenje kvalitete života kod osoba s invaliditetom. Hrvatska revija za rehabilitacijska istraživanja. 2013;49(1):12-24.

5. Bratković D. Kvaliteta življenja osoba s mentalnom retardacijom. Naš prijatelj: Časopis za pitanja mentalne retardacije. 2003;30(1/2):5-22.

6. Aljinović Ratković N, Uglešić V, ur. Kako poboljšati kvalitetu života bolesnika s rakom glave i vrata. Hrvatsko društvo za maksilofacijalnu, plastičnu i rekonstrukcijsku kirurgiju glave i vrata. Zagreb: Klinička bolnica Dubrava; 2006.

7. Prgomet D. Zloćudni tumori grkljana. U: Katić V, Prgomet D i sur. Otorinolaringologija i kirurgija glave $i$ vrata. Zagreb: Naklada Ljevak; 2009. 293-9.

8. Nikšić Ivančić M. Zloćudni tumori grkljana. U: Bumber Ž, Katić V, Nikšić -Ivančić M i sur. Otorinolaringologija. Zagreb: Naklada Ljevak; 2004. 273-5.

9. Hrvatski zavod za javno zdravstvo, Registar za rak. Incidencija raka u Hrvatskoj 2012. Bilten 37. Zagreb, 2014.

10. Manish J, Pankaj C, Prathamesh P, Devendra C, Gauri P, Anil D. Carcinoma Larynx in Children. International Journal of Head and Neck Surgery. 2010;1(1):49-51.

11. Terrell JE, Ronis DL, Fowler KE, Bradford CR, Chepeha DB, Prince ME, Teknos TN, Wolf GT, Duffy SA. Clinical predictors of quality of life in patients with head and neck cancer. Archives of otolaryngology - head \& neck surgery. 2004;130(4):401-8.

12. Graeff A, Leeuw JR, Ros WJ, Hordijk GJ, Blijham GH, Winnubst JA. Pretreatment factors predicting quality of life after treatment for head and neck cancer. Head and neck. 2000;22(4):398-407.

13. Cummins RA, Eckersley R, Pallant J, van Vugt J, Misajon R. Developing a national index of subjective wellbeing: the Autralian unity wellbeing index. Social Indicators Research. 2003;64:159-190.

14. International Wellbeing Group Personal Wellbeing Index: 5th Edition. Melbourne: Australian Centre on Quality of Life, Deakin University; 2013.

15. Kaliterna Lipovčan Lj, Burušić J, Tadić M. Indikatori kvalitete življenja. U: Božičević V, Brlas S, Gulin M, ur. Psihologija u zaštiti mentalnog zdravlja - Priručnik za psihološki djelatnost u zaštiti i promicanju mentalnog zdravlja. Virovitica: Zavod za javno zdravstvo Sveti Rok Virovitičko Podravske Županije; 2012. 
16. Aaronson NK, Ahmedzai S, Bergman B, Bullinger M, Cull A, Duez NJ, Filiberti A, Flechtner H, Fleishman SB, de Haes JC, et al. The European Organization for Research and Treatment of Cancer QLQ-C30: A quality-of-life instrument for use in international clinical trials in oncology. Journal of the National Cancer Institute. 1993;85(5):365-76.

17. Fayers, P, Aaronson, N i sur. The EORTC QLQ-C30 Scoring Manual. Brussels: European Organisation for Research and Treatment of Cancer; 2001.

18. Pinjatela R. Neke karakteristike kvalitete života osoba sa i bez malignog oboljenja. Hrvatska revija za rehabilitacijska istraživanja. 2008;44(2):79-98.

19. Mellor D, Cummins RA, Loquet C. The gold standard for life satisfaction: Confirmation and elaboration using an immaginary scale and qualitative interview. International Journal of Social Research Methodology Theory and Practice. 1999;2(4):263-278.

20. Kazi R, De Cordova J, Kanagalingam J, Venkitaraman R, Nutting CM, Clarke P, Rhys-Evans P, Harrington KJ. Quality of life following total laryngectomy: assessment using the UW-QOL scale. ORL; journal for oto-rhino-laryngology and its related specialties. 2007;69(2):100-6.

21. Singer S, Danker H, Dietz A, Kienast U, Pabst F, Meister E, Oeken J, Thiele A, Schwarz R. Sexual problems after total or partial laryngectomy. The Laryngoscope. 2008; 118(12):2218-24.

22. Tićac R, Tićac B, Maljevac B, Velepić M, Malvić G, Vučković D, Manestar D. Rehabilitacija glasa traheoezofagealnim govornim protezama nakon totalne laringektomije. Medicina. 2009;45(2): 165-71.

23. Fruge E, Crouch M, Bray J. Obiteljska dinamika i zdravlje. U: Rakel RE. Osnove obiteljske medicine. Zagreb: Medicinska biblioteka; 2005: 30-7.

24. Diminić-Lisica I, Rončević-Gržeta I. Obitelj i kronična bolest. Medicina fluminensis. 2010;46(3): 300-8.

25. Grabovac S, Opačić M, Ceronja I, Puharić Z, Bonetti A. IZvještaj o pušenju cigareta među školskom djecom i razlike u kvaliteti života i glasa između bivših pušača - laringektomiranih osoba i zdravih nepušača. Radovi Zavoda za znanstvenoistraživački i umjetnički rad u Bjelovaru. 2013; sv. 7:43-56.

26. Štefanac S, Grabovac I. Radna terapija osoba oboljelih od kronične opstruktivne plućne bolesti. Respiratorni kontinuum, Medicus. 2013;22(2):125-31.

27. Sport for Development and Peace International Working Group. Literature reviews on sport for development and peace. Conceptualizing sport, physical activity and health. Toronto, Canada: 2007. 57-58.

28. Cooper RA, Quatrano LA, Axelson PW, Harlan W, Stineman M, Franklin B, Krause JS, Bach J, Chambers H, Chao EYS, Alexander M, Painter P. Research on physical activity and health among people with disabilities: a consensus statement. Journal of Rehabilitation Research and Development. 1999;36(2):142-54.

29. Abell J, Hootman J, Zack M, Moriarty D, Helmick C. Physical activity and health related quality of life among pe- ople with arthritis. Journal of epidemiology and community health. 2005;59(5):380-5.

30. Groff DG, Lundberg NR, Zabriskie RB. Influence of adapted sport on quality of life: perceptions of athletes with cerebral palsy. Disability and rehabilitation. 2009;31(4):318-26.

31. McVeigh SA, Hitzig SL, Craven BC. Influence of sport participation on community integration and quality of life: a comparison between sport participants and non-sport participants with spinal cord injury. The journal of spinal cord medicine. 2009;32(2):115-24.

32. Mallis A, Goumas PD, Mastronikolis NS, Panogeorgou T, Stathas T, Prodromaki K, Papadas TA. Factors influencing quality of life after total laryngectomy: a study of 92 patients. European Review for Medical and Pharmacological Sciences. 2011;15(8):937-42. 


\section{THE QUALITY OF LIFE AFTER LARYNGECTOMY}

1 Ivana Crnković

1 Melita Rukavina

1 Karlo Ostrogonac

1 University of Applied Health Sciences Zagreb

\section{Abstract}

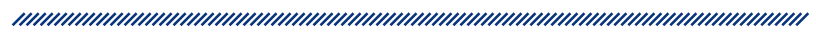

The quality of life is an important evaluation instrument of the rehabilitation process of oncological patients and, thus, of persons who have undergone laryngectomy. The goal of this research was to investigate the degree of the quality of life in persons after laryngectomy as a whole and by domains, to check whether there are any differences in the quality of life of persons before and after laryngectomy as a whole and by domains and to examine the factors influencing the self-evaluation of the quality of life of persons after laryngectomy. The study included 35 respondents who have undergone total laryngectomy. An appropriate sample was taken from the Zagreb region, i.e. from the University Hospital for Tumours of the University Hospital Centre Sestre Milosrdnice in Zagreb and from the Clinic for Tumours of the University Hospital Centre Zagreb. For the purpose of this research, a Personal wellbeing Index was used for the evaluation of the quality of life and wellbeing before and after the laryngectomy, as well as EORTC QLQC30 Questionnaire version 3.0 for the self-evaluation of the quality of life.
The results of the research indicate that the perceived quality of life of persons who have undergone laryngectomy does not deviate from the values which can be found in the healthy population. It was established that the respondents evaluated their quality of life before the intervention as significantly better. The patients who were included in the rehabilitation process and who engaged in physical activity on average evaluated their quality of life as better both before and after the intervention. The symptoms most significantly linked with the sense of wellbeing, i.e. quality of life, were fatigue and gastrointestinal disorders, while the global health scale has been linked only to the quality of life after the intervention.

Keywords: quality of life, persons who have undergone laryngectomy, rehabilitation process, self-evaluation of factors influencing the quality of life after laryngectomy 